\title{
Museer og SuCCES
}

\author{
Janne Laursen
}

Det er ikke en feberkurve, det er heller ikke dagens udsving for dollarkursen. Nej, det er museets besøgstal, som direktøren stirrer forhekset $p a$ a. Trods en voksende interesse $i$ det omgivende samfund for kultur, natur og kunst "trakker» de permanente udstillinger ikke, som de burde. Det gør til gengald sarudstillinger, aktiviteter og i sardeleshed levendegørelse.

\section{DEN UDSTILLEDE HISTORIE PA MUSEERNE}

Særudstillinger - og når publikum kan skyde med bue og pil, ælte dej, klæde sig ud, kærne smør og lege med ler - det øger besøgstallet. Når der er adgang på museerne bag kulisserne og konservatorerne demonstrerer deres know-how, så er det også meget interessant.

Ikke desto mindre fastholder museerne en udstillingstradition, formmæssigt såvel som indholdsmæssigt, der ikke levner plads til at vise alt dette spændende, der interesserer publikum så meget. Det forbliver - særarrangementer. Det er ikke historien. I alt fald ikke for museumsfolk.

$\mathrm{Nu}$ mener jeg ikke, at museer skal være institutioner, der bare leverer det publikum vil have. Publikum kan kun forholde sig til det allerede kendte og vil derfor aldrig kunne efterspørge det endnu ikke formulerede eller prøvede. Så den strategi leder ikke til nyudvikling af nogen art. Der er ikke desto mindre et misforhold mellem besøgstal til permanente udstillinger og særarrangementernes besøgstal, som rejser nogle spørgsmål. Rettere: Det kan undre, at museumsfolk ser denne udvikling til fordel for særarrangementer og det «eventprægede» så snævert. For den er da kun et udtryk for, at det centrale fundament - synliggjort ved den permanente udstilling - ikke er den historie, det interesserer publikum så forfærdelig meget at stifte nærmere bekendtskab med.

Det nytter ikke meget at raffinere informationsapparatet og formidlingen på museerne, hvis det museet beskæftiger sig med eller måden det sker på, opleves uden relevans for et flertal af individer nu og her. Helt ærlig, så er mange permanente udstillinger da også ubegribelige. Hvad har de på hjerte? Hvad rummer de af relevans og mulig identifikation for publikum i dag?

\section{DEN NEMME LØSNING}

Det er langt enklere at pille nogle temaer ud af det store materiale, de fleste museer rummer og lade det være genstand for en særudstilling eller andet særarrangement, end det er at arbejde med permanente 
102 udstillinger. De repræsenterer en helt anden og sværere opgave af mere overordnet karakter.

Her tror jeg, at en del museumsfolk kommer til kort. De enkelte faginspektører har specialiseret sig i snævre områder eller er ikke vant til overordnet at problematisere museets samlede virkeområde og materiale, så det får relevans i forhold til et givent museums målsætning. Også det begunstiger en udvikling til fordel for det partielle - særarrangementer og det "eventprægede».

Overblikket og problematiseringen af et museums arbejdsområde er så central en opgave, at en del direktører nok også mener, det er dem, der skal sætte dagsordenen, omend det forudsætter en fordybelse, de færreste ledere har mulighed for at give sagen. Der er en arbejdsopgave her, hvis sande karakter alt for længe har været en hemmelighed.

Der er tale om noget, der er svært. Sværere end hidtil antaget. Den opgave er tankens arbejde - den er filosofisk og kulturvidenskabelig orienteret, men den kan ikke løses uden at være integreret $\mathrm{i}$ den baggrund et givent museum repræsenterer af egen "virksomhedskultur» og håb for fremtiden.

Virksomhedskultur studeres med ihærdighed af mere avancerede handelshøjskoleforskere for dens konsekvens - på godt og ondt - for virksomheders evne til at nyudvikle sig. Men ulig erhvervslivet, har museumsverdenen ingen vidensproduktion af den karakter overhovedet. Nok vidensproduktion om vikinger, dragter, bygninger etc., men ikke vidensproduktion om de institutioner, arbejdet foregår på. Der mangler kort sagt en museernes egen museologiske virksomhedsanalyse, der som andre arbejdsredskaber kan tjene til indholdsmæssig afklaring og strategisk planlægning på museerne.

Det nemme er imidlertid at lukke øjnene for sig selv som institution og springe over, hvor gærdet er lavest. Det er absolut nemmest at lægge sig op ad de kvantitative succeskriterier, hvor besøgstallet og begivenhedskulturen er en skrue uden ende. Det er absolut nemmest at låne berømte genstande og udstille dem på museet, når museet ikke i kraft af sig selv kan sandsynliggøre, at det er et besøg værd.

Det er da også muligt, museet ikke er et besøg værd og aldrig kan opleves som af værdi for så forfærdelig mange. Men det bør man da hellere se i øjnene, i stedet for at stille sig selv den umulige opgave at ville gøre museet til en stor succes for den samlede menneskehed.

\section{MUSEERNES SUCCESKRITERIER}

Museer er til for alle, forlyder det ofte om museernes målgruppe. Som følge heraf må museet også være en voksende succes jo flere, der passerer tælleapparatet. Sådan er det også med aviser. De er til salg for alle, det er bare ikke alle, der køber dem. TV er også til for alle. Det er bare ikke alle, der ser de samme programmer.

Museernes jagt på et voksende besøgstal, avisernes konkurrence om voksende oplag og de enkelte tv-stationers ønske om voksende seertal, er den type af kvantitativ succeskriterie, der råder $\mathrm{i}$ det private erhvervsliv. Her er devisen: Øget forbrug, øget omsætning, øget fortjeneste. Dybest set er det ligegyldigt, om sagen drejer sig om tandpasta, øl, vaskepulver eller støvsugere, museer, tv-programmer eller aviser. 
Der er tale om en måde at tænke på, som er forbløffende enkel, og som bygger på den økonomiske værdi som den enerådende. Det er lige her, friktionerne opstår i forhold til museerne. Deres grundlag handler om andre værdier end den økonomiske værdi. Hvorfor man så på museerne bevidstløst læner sig op ad succeskriterier fra traditionel økonomisk virksomhed er egentlig en gåde af de større. Men det er muligvis en indikation af, hvor massiv og svær opgave det er at ville fremhæve andre værdier end den økonomiske i et samfund, hvor netop den værdi bliver mere og mere dominerende.

Motivationen til at etablere museer er bare en anden sag end motivationen til at anlægge f.eks. et bryggeri. Ingen gider da brygge $ø$ for at glæde sig over synet over de mange flasker. Det er kun noget ved for bryggeriets ejere, når de er solgt.

Museerne er stik modsatte. Her hober genstandene sig op, jo flere jo bedre, og det er en dødsynd og ulovligt at sælge af samlingerne. Nogen skal jo finansiere gildet, men hvordan legitimere udgifter, der tilsyneladende forsvinder ned i et bundløst hul uden at kunne tilbyde et klart og tydeligt svar på "return of investment"?

Det svar har museumsfolk svært ved at formulere overbevisende og skudsikkert. For hvad er egentlig meningen med alle disse museer? Den er ofte så indforstået en sag blandt museumsfolk, at træning $\mathrm{i}$ at formulere sig herom er forfærdende fraværende. Ikke desto mindre, vil fremtidens behov for evnen til at argumentere for og legitimere museernes virke ikke kunne klares med en henvisning til kulturarvens store betydning. Det er ikke længere nok.

Den store fokusering på besøgstallet og begivenhedskulturen som succeskriterier implicerer ikke nogen synderlige krav om en sammenhængende strategi for museets indholdsmæssige arbejde. Hersker der internt på museet uklarhed om, hvad formålet er med arbejdet, ud over at skaffe flere besøgende og stadig større presseomtale, så er fanden løs. For hvilke retningslinjer for det indholdsmæssige arbejde på museerne har personalet så at forholde sig til? Ingen ud over en zig-zag kurs dikteret af troen på, hvad der med mindst mulig investering kunne være en «kiosk-basker». Har museet et troværdighedsproblem indadtil, så har det i kraft af de arbejdsresultater, der skabes med et sådant fundament også ganske automatisk et troværdighedsproblem udadtil.

En del museer har faktisk sådanne troværdighedsproblemer. De er mest tydelige for de kulturhistoriske museers vedkommende. Kulturarvens store værdi er åbenbart sværere at omsætte i arbejdsresultater med stor gennemslagskraft og relevans for offentligheden end hidtil antaget.

Målsætningsdebatter og heraf afledte succeskriterier af mere nuanceret karakter end blot og bar et voksende besøgstal, vil en del museumsfolk nok mene, de allerede har brugt rigelig tid på. Det bliver opgaven ikke nødvendigvis løst af. Det fortæller bare noget om, hvor svær den er.

\section{MOTIVATIONERNE TIL MUSEERS EKSISTENS: NY MUSEUMSTYPOLOGI}

Er museernes primære formål overhovedet at udstille historie? Det er jeg ikke overbevist om. Museernes primære formål er at tilfredsstille de motivationer, der har afstedkommet deres eksistens. Det afspejler sig sekundært i museernes samlinger og den udstillede historie, de enkelte museer 
104 fokuserer på. Besværlighederne med arbejdet på museer kan netop være forårsaget af, at nogen tror det forholder sig omvendt.

Museer er den type af institutioner, der skylder deres tilstedeværelse en anden type af værdiopfattelse end den økonomiske værdi. Der har i alt fald oprindeligt været en mening med galskaben. Museet som instrument for bestemte intentioner er bare en næsten glemt diskussion.

Ikke desto mindre er det en vigtig pointe, at den udstillede historie ikke kan forstås med mindre intentionerne hermed kommer med i vurderingen. Den sag er oplagt at påpege for museerne i det gamle Sovjetunionen og med den nazistiske udstillingsvirksomhed $\mathrm{i}$ det 3 . rige. Men når det gælder os selv nu og her, ser vi gerne vores museer som neutrale, faglige og friholdt sådanne uniformeringer.

Det er karakteren af samlingerne, der ligger til grund for den gængse opdeling af museer i kultur- og naturhistoriske museer samt kunstmuseer. Samlingerne sladrer imidlertid ikke bare om arten, men også om et museums sande identitet - om formålet med et museum. Med udgangspunkt i motivationen til at indsamle og oprette museer kan man godt skabe en helt ny museumstypologi, som går på tværs af den gængse opdeling. Et frisk bud på sådan en lyder:

\section{«Sidste øjebliks-museet»}

Drivkraften til etableringen af sådanne museer er den voldsomme forandring i det industrialiserede samfund, der bestandigt overflødigg ør bestemte produktionsformer og måder at leve på. Det er truslen om tab af identitet og genkendelsen fra det eget liv, der er en væsentlig faktor for sådanne museers evne til at engagere publikum.
Udstillingerne fungerer ofte som et stikordsregister for dem, der kan etablere en genkendelse fra det eget liv. Udstillingerne er derfor et tilbud om et vue i bakspejlet, ikke et vue gennem frontruden. Når de mennesker, der kan genkende noget, ikke findes mere, da befinder et sådant museum sig i en øjeblikkelig identitetskrise. Det må nyfortolke sit grundlag, skifte spor, men til hvilket?

\section{"Prestige-museet»}

Drivkraften til etablering af sådanne museer kan være ønsket om personlig prestige eller ønsket om lokal/regional prestige. I denne kategori befinder sig også det konkurrencemoment, der i særdeleshed i dag er meget væsentligt i byers og regioners ønske om at profilere en attraktionsværdi, der kan opbygge stedets image på en positiv måde og skabe omsætning i forretninger, restauranter m.v.

Det er bare sjældent tankens raffinementer og evne til grænseoverskridelse, der er det prestigegivende for disse museer. Men genstandenes større eller mindre andel af det, der er offentligt godkendt som unikt og enestående. Sådanne museer skal være "noget særligt". Netop derfor kan man her opleve sig $i$ et noget snævert korset, for "noget særligt» for hvem?

I stærkt konformitetssøgende miljøer er grænserne for opfattelsen af «det særlige» meget snævre, hvorfor oprør herfra vil indfinde sig, når museet opleves for grænseoverskridende. Kartoflerne bliver meget hurtigt for varme på sådanne museer. Sagt på en anden måde: Pænheden hærger og har det med at stille sig hindrende $\mathrm{i}$ vejen for netop «det særlige», når det kommer til stykket. Nyudvikling her er ikke nogen lille opgave. 


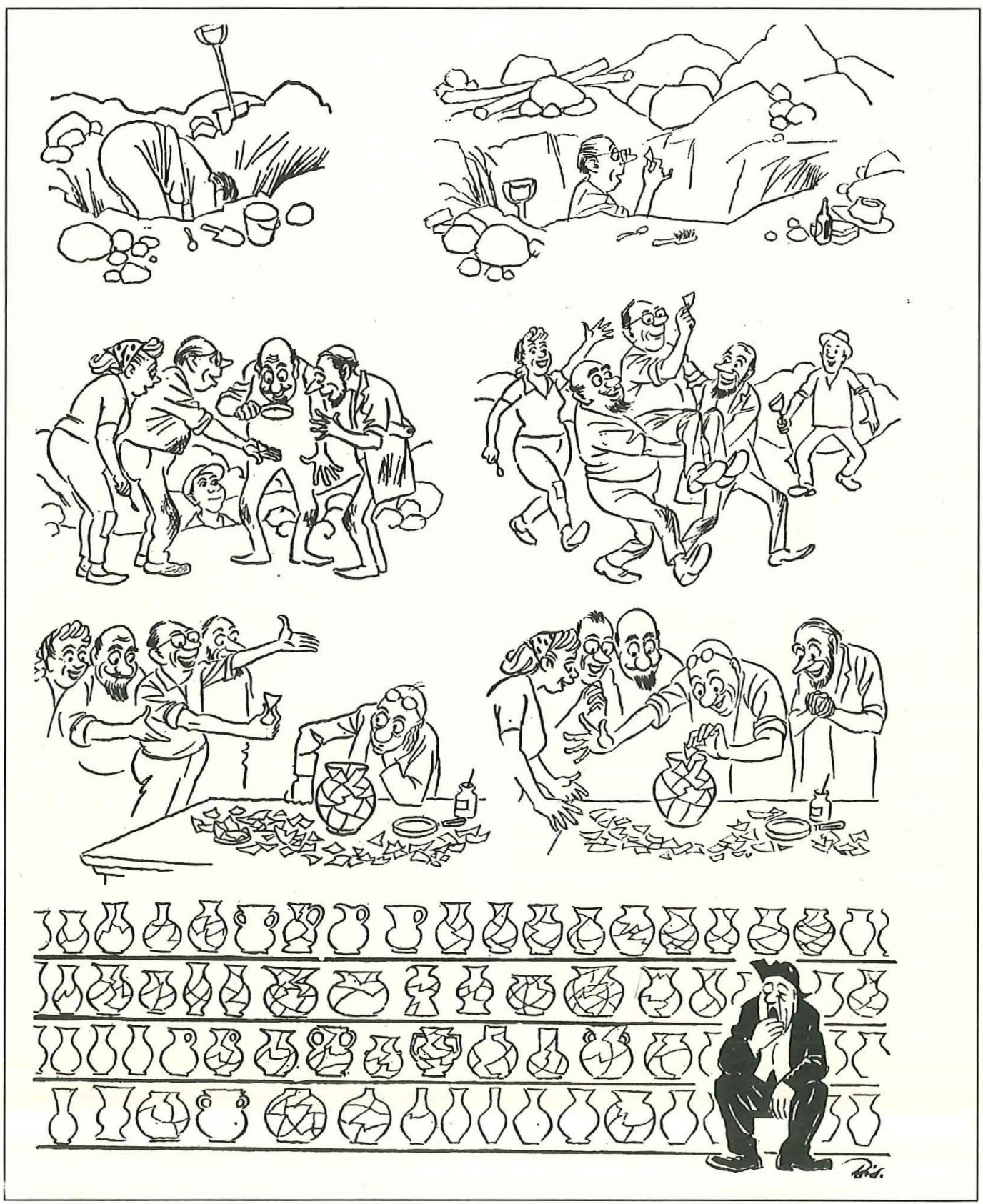

Kvantitative succeskriterier drejer sig ikke bare om museernes besogstal. Tegning af Herluf Bidstrup, fra Land og Folk. 
106 "Opdragendeluddannende museer»

Det opdragende kan gælde opdragelse til nationalfølelse og fædrelandskærlighed (herunder også den regionale variation med hjemstavnen $\mathrm{i}$ fokus) såvel som æstetisk opdragelse.

Når fædrelandskærligheden, hjemstavnskærligheden og spørgsmålet om, hvad der er smukt og grimt og sand kunst ikke længere er så entydigt, da får disse museer et behov for at nyfortolke deres grundlag. De skal skifte spor. Men til hvad? Det gælder også de museer, der som f.eks. de danske universitetsmuseer har samlinger skabt til et særligt uddannelsesmæssigt formål. Deres målgruppe er i sit udgangspunkt meget snæver, hvad den brede offentlighed klart oplever ved besøg på mange af disse museer.

"So ein Ding müssen wir auch haben - museer» Det er måske for meget at ville gøre dette til en selvstændig type af museer, da der i deres motivation indgår et stærkt konkurrencemoment som allerede nævnt ved prestige-museerne. Når det nu alligevel kan forekomme relevant, så skyldes det forskellen mellem en modegrille, der skal forsyne garderoben med et attrået stykke, for hvilket man egentlig hurtigt mister interessen og en virkelig prestigesag.

Det afslører investeringslysten på længere sigt. For et "so ein Ding müssen wir auch haben-museum» er ikke tænkt videre end til dets etablering. Det er nok, at det findes. Museets fortsatte drift og virke bliver derfor en vanskelig sag at vinde forståelse for, hvorfor det egentlig aldrig kommer så meget videre end det var ved sin start.

\section{"Business-museer»}

Her er der ofte tale om en ren og skær for- retningsmæssig motivation og turistmæssige hensyn. Herunder befinder sig også de multikulturelle oplevelsescentre, der skal berøve folk deres tid og penge som det primære formål og sekundært fortælle noget undervejs.

Det interessante forekommer at være det lidet salgbare i det indhold, sådanne museer tilbyder publikum. For den slags museer har det med at få svære økonomiske problemer. Sådan et museum har ufatteligt svært ved at udvikle sig videre, med mindre det forsynes med en anden motivation til dets tilstedeværelse end den rent forretningsmæssige.

\section{PROFESSIONALISERING}

De her nævnte motivationer hænger sammen med den type af industrialiseret samfund, vi lever i. De er lige så gældende i dag som for 100 år siden, og de er stadigt aktive i nye museumsdannelser. Professionaliseringen på museerne handler dybest set om ikke at underkaste sig disse motivationer bevidstløst, men være sig dem bevidst og evne at arbejde hen mod nyfortolkninger.

Motivationsgrundlaget for museer er helt centralt at beskæftige sig med, da det dikterer samtlige spor, der er lagt ud for museets virke. Men hvordan i himlens navn nyfortolker man et sådant og kommer med et bud på fornyet relevans af f.eks. "et-sidste-øjebliks-museum»? $\mathrm{Da}$ skal den umiddelbare reaktion det sidste øjeblik ledte til - nemlig dannelsen af et museum - identificeres som en defensiv reaktion. Akkurat som museet uden tvivl er et defensivt museum. Svaret skal så findes på, hvordan en sådan sag kan vendes om og blive til et offensivt museum med 
et koncept, der garanterer museet relevans i fremtiden og ikke bare for den stadigt mindre gruppe, der delte det sidste øjeblik.

Sådanne bud kan have seriøse konsekvenser for museet og stille nye og helt anderledes krav til museets personale. Men det er i denne indholdsmæssige bearbejdelse af det hidtidige motivationsgrundlag, at museernes reelle mulighed for nyudvikling befinder sig.

Løses den opgave ikke, og løses den ikke godt nok, så vil fundamentets uklarhed medføre forvirring for museets eget personale såvel som for publikum. Besøgstallet kan uimodsagt gå sin sejrsgang som succeskriterie sammen med andre nemme løsninger som f.eks. sporskifte til kategorien "prestigemuseer». Ikke som et nyt bud på, hvad prestige kan være, (der er ikke nødvendigvis noget som helst galt med ønsket om at kunne være stolt af et museum), men som en gentagelse af det allerede kendte og dermed sikre.

\section{MUSEERNES EGEN \\ VIRKSOMHEDSANALYSE}

$\mathrm{Nu}$ kan en vidensudvikling ikke efterspørges, før den erkendes som et behov og opleves som nyttig. Museologien har hidtil levet en noget kummerlig tilværelse. Den har været anset som uhyre interessant, men museerne ser hellere de økonomiske midler investeret i deres drift end i en vidensproduktion om museerne selv. For den vidensproduktion forekommer at være en luksus i forhold til alt det, det vil være for sent at gøre noget ved, hvis ikke der ydes økonomiske tilskud nu og her.

På den måde er museerne ikke bare et resultat af særlige motivationer, men også ofre for dem. Idet man ikke formår at sætte sig ud over deres diktat og indse, hvorfor man altid befinder sig $\mathrm{i}$ en defensiv position og i sidste øjeblik med en hel del på museerne.

Det private erhvervsliv er forsynet med uddannelser og forskningsinstitutioner, der ikke bestiller andet end at lave analyser, støbe og levere kugler til virksomhederne. Den investering, der her er tale om, er på et meget, meget højt niveau. Den er en opbakning virksomhederne læner sig op ad og ikke kan være foruden. Sådan en opbakning har museerne ikke. Det har ingen kulturinstitutioner. De må nasse på brødkrummerne fra de riges bord. Uden tvivl er der også viden og nyttig indsigt at hente der. Bare ikke om den særlige type af virksomhed museer er, idet museer adskiller sig fra virksomheder i det private erhvervsliv ved at være institutioner med kvalitativ målsætning.

Jeg tror på det betydningsfulde $\mathrm{i}$ at tage motivationsgrundlaget for museerne alvorligt. Det grundlag handler nemlig om værdier af stadig mere og mere sjælden karakter, nemlig værdi af anden art end den økonomiske værdi.

Det er dybest set de værdier, jeg tror der er en uformuleret og voksende efterspørgsel på. De handler om følelser og mennesker, det er dem, der kan flytte noget i vores samfund. De værdier er der al mulig grund til at holde fast i og tage alvorlig, såfremt museerne skal bevare betydning og relevans som andet og mere end produkter på lige linje med andre produkter i den almindelige industri.

Virksomhed med kvalitativ målsætning er nok en uendelig meget sværere opgave end at få et bryggeri til at løbe rundt. Det synes jeg ikke, der er grund til at fortie, 
108 ligesom jeg ingen grund ser til den parathed til knæfald for de kvantitative målsætningers dominans og almindelige hærgen. Det er udviklingen, siger nogen. Det kunne også være udtryk for ledelsesmæssig uafklarethed på museerne. Den synes jeg er helt $\mathrm{i}$ orden. Det kan aldrig være lederes opgave at have svar på alt, derimod må det være opgaven at stille de centrale spørgsmål og få fremskaffet svarene.

En generel diskussion om, hvilke andre succeskriterier museerne bør have end kvantitative succeskriterier mener jeg ikke fører til så forfærdelig meget på et abstrakt og generelt niveau. Museerne har forskelligt motivationsgrundlag og må således også udvikle forskellige succeskriterier.

Der skal konkrete eksempler til, før relevansen af en museernes egen virksomhedsanalyse vil fremstå indlysende klar for det store potentiale af efterspørgere, den har. Det er helt afgørende, at museernes ledere har modet til at stille de centrale spørgsmål og søge dem besvaret, selv om de svar ikke er deres egne. Jeg vil afslutningsvis påpege, at ingen med modet til det nogensinde kan undværes på museerne. Det er den slags initiativer, der vil afgøre museernes fremtid. Ikke spor andet.

\section{SUMMARY}

Museums and success

In a world where economic values increasingly dominate museums have a hard job trying to find understanding for values other than the economic ones. The predominance of economic values in society is accompanied by their criteria of success: increased consumption, growing turn-over and more profit. It is difficult for the museums to point to other and more sophisticated criteria for success.

It is suggested that the motivations for establis- hing museums should be the basis of a new classification of museums rather than the traditional division in art museums, museums of cultural history and museums of natural history.

Qualitative values are the basis for the existence of museums, and is it not a much more difficult job to run an institution where you pursue qualitative goals? Even if those who run the museums are competent they lack the support that educational and research institutions give to those who will emerge to lead the traditional business world. The institutions provide these leaders with the tools of success and permanent professional training and refinement.

As the foundations and the objectives of museums are qualitative, they cannot only rely on the traditional training programs for business leaders. It is therefore recommended, that the museums invest in a program for «museological company analysis" - and the sooner the better. One of the main reasons for this is to establish a new interpretation of the motivations for creating museums and criteria of success more specific to museums as they do not regard increased consumption, better turn-over and more profit as their primary objectives.

Janne Laursen er mag. art. i europaisk etnologi. Har arbejdet med formidling og museologi. Seneste udstilling: "Kobenhavn under Jorden", Kobenhavns Bymuseum, 1992. Har lost konsulentoppgaver og undervist på univetsitet og Museumshojskolen i formidling, museologi samt kultur og turisme.

Adr. Olfert Fischersgade 53, 3.

DK-1311 Kobenhavn K, fax $+45-33114405$ 